\title{
Potensi Antiseptik Poliherbal Daun Sirih (Piper Betle), Kulit Jeruk Nipis (Citrus Aurantifolia) Dan Tanaman Bundung (Actinuscirpus Grossus) Pada Tindakan Keperawatan Dan Kebidanan
}

\author{
Darini Kurniawati 1, Noval 2, Kunti Nastiti 3 \\ Program Studi Sarjana Farmasi, Fakultas Kesehatan, Universitas Sari Mulia \\ * correspondence author: Handphone: 081263747809, E-mail: Srilina46@gmail.com
}

DOI: https://doi.org/10.33859/dksm.v11i1.552

\begin{abstract}
Abstrak
Latar Belakang: Antiseptik adalah senyawa kimia yang digunakan untuk membunuh atau menghambat pertumbuhan mikroorganisme pada jaringan yang hidup seperti permukaan kulit dan membran mukosa. Daun sirih, jeruk nipis, bundung sudah banyak digunakan masyarakat untuk obat. Antiseptik dari poliherbal diyakini lebih aman dari pada zat kimia sintetis.

Tujuan: Tujuan penelitian ini untuk mengetahui kemampuan antiseptik terhadap bakteri Staphylococcus aureus dari campuran ekstrak daun sirih, jeruk nipis dan bundung sebagai pengganti antiseptic dari bahan zat kimia sintetis pada tindakan keperawatan dan kebidanan.

Metode: Metode penelitian adalah eksperimental dengan membuat formulasi uji konsentrasi $\mathrm{F} 1$ 20\%, F2 30\%, F3 F4 40\% dan F5 50\% dan diujikan terhadap bakteri Staphylococcus aureus dengan metode difusi disk.

Hasil: Hasil penelitian menunjukkan bahwa daya antiseptik Daun Sirih, Jeruk Nipis dan Bundung efektif sebagai antiseptic pada konsentrasi $40 \%$ dengan efektifitas yang sama dari bahan antiseptic zat kimia sintetis. Konsentrasi F1 20\% tidak ada daya hambat dengan nilai yang sama pada kontrol negatif, pada F2 30\% terdapat daya hambat lemah sebesar $7 \mathrm{~mm}$, pada F3 $40 \%$ terdapat daya hambat kuat sebesar $23 \mathrm{~mm}$ sama dengan kontrol positif, dan pada F4 50\% terdapat daya hambat sangat kuat lebih besar dari kontrol positif yaitu $40 \mathrm{~mm}$.

Simpulan: Antiseptik dari bahan alam kombinasi Daun Sirih, Jeruk Nipis dan Bundung pada konsentrasi $40 \%$ mempunyai efektifitas antiseptic yang sama dari antiseptic dengan bahan zat kimia sintetis. Antiseptik poliherbal ini bisa digunakan untuk keperluan tindakan keperawatan dan kebidanan.
\end{abstract}

Kata Kunci: Daun sirih, kulit jeruk nipis, tanaman bundung, antiseptik, tindakan keperawatan dan kebidanan 


\begin{abstract}
Background: Antiseptic is a chemical compound that is used to kill or inhibit the growth of microorganisms in living tissues such as the surface of the skin and mucous membranes. Betel leaf, lime, bundung have been widely used by the community for medicine. Antiseptics from polybals are believed to be safer than synthetic chemicals.

Objective: The purpose of this study was to determine the antiseptic ability of Staphylococcus aureus bacteria from a mixture of betel, lime and bundung extracts as an antiseptic substitute for synthetic chemicals in nursing and obstetrics.

Methods: The research method was experimental by making test formulations with concentrations of F1 20\%, F2 30\%, F3 F4 40\% and F5 50\% and tested against Staphylococcus aureus bacteria using the disk diffusion method.

Results: The results showed that the antiseptic power of Betel, Lime and Bundung leaves was effective as an antiseptic at a concentration of $40 \%$ with the same effectiveness of synthetic chemical antiseptic substances. The concentration of F1 20\% has no inhibitory power with the same value in the negative control, at F2 30\% there is a weak inhibitory power of $7 \mathrm{~mm}$, at F3 $40 \%$ there is a strong inhibitory power of $23 \mathrm{~mm}$ equal to the positive control, and at F4 50\% there is Very strong inhibition power is greater than positive control, which is $40 \mathrm{~mm}$.

Conclusion: Antiseptic made from natural ingredients a combination of Betel, Lime and Bundung Leaves at a concentration of $40 \%$ has the same antiseptic effectiveness as antiseptic with synthetic chemical substances. This polyerbal antiseptic can be used for the purposes of nursing and midwifery action.
\end{abstract}

Keywords: Betel leaf - lime peel - bundung plant, antiseptic, nursing and midwifery action

\section{Pendahuluan}

Antiseptik adalah senyawa kimia yang digunakan untuk membunuh atau menghambat pertumbuhan mikroorganisme pada jaringan yang hidup seperti permukaan kulit dan membran mukosa (Levinson, 2008). Antiseptik berbeda dengan antibiotika dan desinfektan yaitu antibiotika digunakan untuk membunuh mikroorganisme di dalam tubuh dan diseinfekstan digunakan untuk membunuh mikroorganisme pada benda mati seperti meja, wastafel, dll (Madigan et al., 2006). Namun antiseptik yang kuat dapat dialihfungsikan menjadi desinfekstan, contoh fenol yang dapat digunakan baik sebagai antiseptik maupun desinfektan (Jain, 2004). Penggunaan antiseptik sangat direkomendasikan ketika terjadi epidemi penyakit, bahkan seperti saat ini terjadi pandemi Corona Virus Disease (Covid-19), karena dapat memperlambat penyebaran penyakit atau dapat memutus mata rantai penyebaran penyakit (Health, 2008). 
Dinamika Kesehatan Jurnal Kebidanan dan Keperawatan Vol 11 No. 1 Juli 2020 ( ISSN: 2086-3454 EISSN: 2549-4058)

url: http://ojs.dinamikakesehatan.unism.ac.id DOI : https://doi.org/10.33859/dksm.v11il

Potensi Antiseptik Poliherbal Daun Sirih (Piper Betle), Kulit Jeruk Nipis (Citrus Aurantifolia) Dan Tanaman Bundung (Actinuscirpus Grossus) Pada Tindakan Keperawatan Dan Kebidanan

Efektivitas antiseptik dalam

membunuh mikroorganisme bergantung

pada beberapa faktor, misalnya konsentrasi

dan lama paparan (Block, 2001). Pada

konsentrasi rendah, beberapa antiseptik

menghambat biokimia membran bakteri,

tetapi tidak akan membunuh bakteri tersebut

(Franklin \& Snow, 2005). Ketika konsentrasi

antiseptik tinggi, komponen antiseptik akan

berpenetrasi ke dalam sel dan mengganggu

fungsi normal seluler secara luas termasuk

menghambat biosintesis (pembuatan)

makromolekul dan presipitasi protein

intraseluler dan asam nukleat (DNA atau

RNA) (Franklin \& Snow, 2005). Lama

paparan antiseptik dengan banyaknya

kerusakan pada sel mikroorganisme

berbanding lurus (Franklin \& Snow, 2005).

Mekanisme kerja antiseptik terhadap

mikroorganisme berbeda-beda, misalnya

dengan mendehidrasi (mengeringkan)

bakteri, mengoksidasi sel bakteri,

mengkoagulasi (menggumpalkan) cairan di

sekitar bakteri, atau meracuni sel bakteri

(Gotter, 2018). Beberapa contoh antiseptik diantaranya adalah hydrogen peroksida,

garam mercuri, boric acid, triclosan, povidone iodine dan Polyyhexamethylene Biguanid (PHMB) (Franklin \& Snow, 2005)

Pemakaian antiseptik pada tindakan keperawatan dan kebidanan untuk beberapa keperluan, mencuci tangan, membersihkan ruang operasi sebelum dan sesudah tindakan operasi, membersihkan kulit bagian luka tubuh yang akan dilakukan pembedahan, membersihkan bagian yang disiapkan untuk disuntik, baik sebelum maupun sesudah ditusuk jarum, dan membersihkan kulit secara keseluruhan (Gotter, 2018).

Pemanfaatan bahan alam sebagai obat tradisional akhir-akhir ini meningkat. Penggunaan obat tradisional dinilai memiliki efek samping lebih kecil dibandingkan dengan obat yang berasal dari bahan kimia dan harganya lebih terjangkau. Delapan puluh persen penduduk Indonesia hidup di pedesaan dan kadang sulit dijangkau oleh tim medis dan obat-obatan modern. Mahalnya biaya pengobatan 
Dinamika Kesehatan Jurnal Kebidanan dan Keperawatan Vol 11 No. 1 Juli 2020 ( ISSN: 2086-3454 EISSN: 2549-4058) url: http://ojs.dinamikakesehatan.unism.ac.id DOI : https://doi.org/10.33859/dksm.v11i1

Potensi Antiseptik Poliherbal Daun Sirih (Piper Betle), Kulit Jeruk Nipis (Citrus Aurantifolia) Dan Tanaman Bundung (Actinuscirpus Grossus) Pada Tindakan Keperawatan Dan Kebidanan

modern menyebabkan masyakat

keanyakan berpaling ke obat tradisional yang berasal dari alam (Putri, 2010).

Daun sirih dimanfaatkan sebagai antisariawan, antibatuk, adstringent dan antiiseptik. Kandungan kimia tanaman sirih adalah saponin, flavonoid, polifenol dan minyak atsiri. Senyawa saponin bekerja merusak membran sitoplasma dan membunuh sel mikroba. Flavonoid diduga memiliki mekanisme kerja mendenaturasi protein sel bakteri dan merusak membran sel tanpa dapat diperbaiki lagi (Aiello \& Susan, 2012).

Daun sirih mempunyai aroma yang khas karena mengandung minyak atsiri, air, protein, lemak, karbohidrat, kalsium, fosfor, vitamin A,B,C, yodium, gula dan pati. Fenol alam yang terkandung dalam minyak atsiri memiliki daya antiseptik 5 kali lebih kuat dibandingkan fenol biasa (bakterisid dan fungisid) tetapi tidak sporasid (Putri, 2010).

Jeruk nipis (Citrus aurantifolia) adalah tanaman poliembrionik yang ditanam di berbagai negara. Di Indonesia banyak terdapat tanaman ini karena iklimna yang tropis.jeruk nipis adalah salah satu tanaman yang banyak digunakan oleh masyarakat Indonesia baik sebagai bumbu masakan ataupun secara empirik digunakan sebagai obat batuk, meluruhkan dahak, influenza dan jerawat (Lauma, Pangemanan, \& Hutagalung, 2015).

Jeruk nipis memiliki berbagai kandungan senyawa kimia yang bermanfaat yaitu asam sitrat, asam amino (triptofan dan lisin), minyak atsiri (sital, limonen, geranilasetat, linalilasetat, felandren, kadinen, aktildehid, nonildehid) glikosida, lemak, damar, asam sitrun, kalsium, fosfor, besi, belerang vitamin B, dan C. Selain jeruk nipis juga mengandung saponin dan flavonoid, yaitu hesperidin, naringin, tangeretin, eriocotrin, dan eriocitrocid (Putri, 2010).

Tanaman Bundung (Actinuscirpus Grossus) banyak tersebar di Kalimantan dan banyak digunakan oleh masyarakat secara empiris sebagai antimikroba. Hasil uji fitokimia dari penelitian Noval dkk 
Dinamika Kesehatan Jurnal Kebidanan dan Keperawatan Vol 11 No. 1 Juli 2020 ( ISSN: 2086-3454 EISSN: 2549-4058) url: http://ojs.dinamikakesehatan.unism.ac.id DOI : https://doi.org/10.33859/dksm.v11il

Potensi Antiseptik Poliherbal Daun Sirih (Piper Betle), Kulit Jeruk Nipis (Citrus Aurantifolia) Dan Tanaman Bundung (Actinuscirpus Grossus) Pada Tindakan Keperawatan Dan Kebidanan

menunjukkan ekstrak etanol tanaman bundung mengandung golongan senyawa metabolit sekunder yaitu flavonoid, tannin, saponin, fenolik, steroid dan terpenoid (Noval et al., 2020; Noval et al., 2020; Noval et al., 2019).

Staphylococcus aureus merupakan satu diantara 5 jenis bakteri yang hidup di kulit manusia yaitu Propionibacterium acnes, Corynebacterium, Staphylococcus epidermidis, Staphylocoocus aureus dan Streptococcus pyogenes. Staphylococcus aureus ditemukan pada kulit dan selaput lendir manusia dan banyak hewan. Bakteri ini tidak berbahaya, tetapi infeksi dapat terjadi pada kulit yang rusak atau dalam keringat yang tersumbat atau kelenjar sebaceous. Staphylococcus aureus adalah jenis bakteri kulit yang umum dapat ditemukan di berbagai bidang seperti kulit, rongga hidung dan saluran pernnapasan. Staphylococcus aureus biasanya menyebar melalui kontak fisik dan harus menembus kulit, melalui luka dan bisa menyebabkan infeksi. Staphylococcus aureus banyak terdapat di sekitar kita. Jika tidak hati-hati, bisa menimbulkan infeksi. Oleh karena itu, kita perlu pencegahan dengan cara rajin mencuci tangan dengan sabun/ antiseptik tangan dan tidak berbagi penggunaan barang pribadi dengan orang lain (Stoppler \& Net, 2019).

Tujuan penelitian ini untuk mengetahui kemampuan menghambat atau membunuh bakteri Staphylococcus Aureus dari tiga campuran ekstrak tanaman daun sirih (Piper betle), kulit jeruk nipis (Citrus aurantifolia) dan tanaman bundung (Actinuscirpus Grossus) dengan menggunakan metode difusi disk terhadap bakteri Staphylococcus aureus, dari formulasi $20 \% \mathrm{~b} / \mathrm{v}, \quad 30 \% \mathrm{~b} / \mathrm{v}, \quad 40 \% \mathrm{~b} / \mathrm{v}$ dan $50 \% \mathrm{~b} / \mathrm{v}$ dengan menggunakan kontrol positif cairan antiseptik.

\section{Bahan dan Metode}

Penelitian ini adalah penelitian eksperimental dengan menguji potensi ekstrak poliherbal dengan variasi konsentrasi F1 20\%, F2 30\%, F3 40\% dan 
Dinamika Kesehatan Jurnal Kebidanan dan Keperawatan Vol 11 No. 1 Juli 2020 ( ISSN: 2086-3454 EISSN: 2549-4058)

url: http://ojs.dinamikakesehatan.unism.ac.id DOI : https://doi.org/10.33859/dksm.v11il

Potensi Antiseptik Poliherbal Daun Sirih (Piper Betle), Kulit Jeruk Nipis (Citrus Aurantifolia) Dan Tanaman Bundung (Actinuscirpus Grossus) Pada Tindakan Keperawatan Dan Kebidanan

F4 $50 \%$ menggunakan metode difusi disk

terhadap bakteri Staphylococcus aureus.

Bahan dan alat yang digunakan:

bakteri Staphylococcus aureus, media

Nutrient Agar, $\mathrm{NaCl}$, Nutrient Broth, daun

sirih, jeruk nipis, tanaman bundung, panci

infusa, kompor gas, toples kaca, gelas

beker, batang pengaduk, saringan dan

kertas saring, timbangan analitik, etanol

95\%, aquades, cawan petri, stirrer

magnetic, autoklaf, kulkas, evaporator,

tangkai ose, tabung reaksi, $\mathrm{NaCl}$ infuse,

vortex, BSC (Biological Safety Cabinet), inkubator, wraping plastic, pinset, tangkai segitiga penyebar, gunting, pisau, telenan, gelas ukur, blender, kertas perkamen.

Proses ekstraksi kulit jeruk nipis (Citrus aurantifolia) dan tanaman bundung (Actinuscirpus Grossus) sebelumnya dicuci bersih, diiris-iris tipis dan dijemur secara tidak langsung selama 3 hari, menjadi simplisia kering, dikecilkan ukuran simplisianya dengan blender menjadi simplisia kecil dan ditimbang, kemudian dimaserasi selama 3 hari dengan etanol
$96 \%$ disertai pengadukan setiap hari. Hasil maserasi disaring dan diukur volumenya, diuapkan dengan evaporator $40 \mathrm{rpm}, 50^{\circ} \mathrm{C}$, hingga diperoleh ekstrak kental.

Pembuatan infusa daun sirih (Piper

bitle L) pertama-tama dicuci bersih dan ditiriskan sampai kering, kemudian ditimbang sesuai pembuatan formulasi dan ditambahkan aquades yang telah dipanaskan, kemudian dimasukkan ke dalam panci infus yang airnya telah mendidih, kemudian distem selama 15 menit (Noval et al., 2017). Panci infus didinginkan, kemudian infusa daun sirih disaring dan didapatkan larutan infusa daun sirih dengan konsentrasi sesuai formulasi.

Pembuatan formulasi dengan mencampur ekstrak kulit jeruk nipis, ekstrak tanaman bundung dilarutkan dengan cairan infusa daun sirih sesuai formulasi pada tabel 1 sebagai berikut

Tabel 1 Formulasi larutan uji campuran infusa daun sirih, ekstrak kulit jeruk dan ekstrak bundung.

\begin{tabular}{llllll}
\hline \multirow{2}{*}{ No } & \multicolumn{2}{c}{ Bahan } & \multicolumn{4}{c}{ Formulasi (gram) } \\
\cline { 3 - 6 } & & F1 & F2 & F3 & F4 \\
\hline 1 & $\begin{array}{l}\text { Infusa daun } \\
\text { sirih }\end{array}$ & $20 \%$ & $30 \%$ & $40 \%$ & $50 \%$ \\
2 & $\begin{array}{l}\text { Ekstrak kulit } \\
\text { jeruk nipis }\end{array}$ & 8 & 8 & 8 & 8
\end{tabular}


Dinamika Kesehatan Jurnal Kebidanan dan Keperawatan Vol 11 No. 1 Juli 2020 ( ISSN: 2086-3454 EISSN: 2549-4058) url: http://ojs.dinamikakesehatan.unism.ac.id DOI : https://doi.org/10.33859/dksm.v11i1

Potensi Antiseptik Poliherbal Daun Sirih (Piper Betle), Kulit Jeruk Nipis (Citrus Aurantifolia) Dan Tanaman Bundung (Actinuscirpus Grossus) Pada Tindakan Keperawatan Dan Kebidanan

\begin{tabular}{llcccc}
3 & $\begin{array}{l}\text { Ekstrak } \\
\text { Tanaman } \\
\text { Bundung } \\
\text { Aquadest ad }\end{array}$ & 100 & 100 & 100 & 100 \\
\hline
\end{tabular}

Pembuatan media Nutrient Agar dengan cara menimbang bahan media sebanyak 7 gram dan dilarutkan dengan 350 $\mathrm{ml}$ aquades yang telah dipanaskan. Tuang ke dalam masing-masing cawan petri yang sudah disterilkan di autoklaf selama 15 menit pada suhu 121 oC. Masing-masing media di cawan petri ditambah $1 \mathrm{ml}$ Nutrient Broth dan1 ml suspensi bakteri Staphylococcus aureus yang sudah diencerkan dengan $\mathrm{NaCl}$, jumlah bakteri telah disesuaikan dengan standar MC Farland $( \pm 3 \times 108)$ lalu dibiarkan selama 60 menit. Kemudian cakram yang sudah direndam selama kurang lebih 15 menit dengan larutan uji F1 20\%, F2 30\%, F3 $40 \%$ dan F4 50\%, serta kontrol positif cairan antiseptik dan kontrol negatif aquades diletakkan di atas media yang sudah berisi bakteri Staphylococcus aureus. Cawan petri tersebut dibungkus dengan wrapping plastic, dan dimasukkan dalam lemari inkubator $37^{\circ} \mathrm{C}$ selama 24 jam.
Berdasarkan tabel 2 pengamatan aktivitas daya hambat terhadap bakteri Staphyloccus aureus setelah diinkubasi 24 jam dapat melihat dengan mengukur diameter zona daya hambat pada tabel di bawah ini (Fuadi, 2014).

Tabel 2 Kekuatan Aktivitas Antibakteri menurut Davis dan Stout

\begin{tabular}{cc}
\hline Kode & Diameter Zona Hambat \\
\hline Lemah & $\leq 10$ \\
Sedang & $11-15$ \\
Kuat & $16-20$ \\
Sangat kuat & $>20$ \\
\hline
\end{tabular}

\section{Hasil}

Tabel 3 Diameter Zona Hambat Terhadap Pertumbuhan Bakteri Stapylococcus Aureus

\begin{tabular}{cc}
\hline Formulasi & Diameter Zona Hambat \\
\hline F1 20\% & $0 \mathrm{~mm}$ \\
F2 30\% & $7 \mathrm{~mm}$ \\
F3 40\% & $23 \mathrm{~mm}$ \\
F4 50\% & $40 \mathrm{~mm}$ \\
Kontrol - & $0 \mathrm{~mm}$ \\
Kontrol + & $23 \mathrm{~mm}$ \\
\hline
\end{tabular}

Berdasarkan hasil pengukuran diameter zona hambat pertumbuhan bakteri Staphylococcus aureus pada tabel 3 menunjukkan adanya aktivitas pada F4 50\% sangat kuat lebih besar dari kontrol positif dengan nilai daya hambat $40 \mathrm{~mm}$, pada F3 $40 \%$ juga berada pada rentang sangat kuat dengan nilai yang sama pada kontrol positif 
Dinamika Kesehatan Jurnal Kebidanan dan Keperawatan Vol 11 No. 1 Juli 2020 ( ISSN: 2086-3454 EISSN: 2549-4058) url: http://ojs.dinamikakesehatan.unism.ac.id DOI : https://doi.org/10.33859/dksm.v11il

Potensi Antiseptik Poliherbal Daun Sirih (Piper Betle), Kulit Jeruk Nipis (Citrus Aurantifolia) Dan Tanaman Bundung (Actinuscirpus Grossus) Pada Tindakan Keperawatan Dan Kebidanan

yaitu $23 \mathrm{~mm}$. Sedangkan pada F2 30\%

berada pada nilai $7 \mathrm{~mm}$ pada zona lemah. F1

$20 \%$ tidak ada daya hambat dengan nilai yang sama pada kontrol negatif yaitu $0 \mathrm{~mm}$.

Dari hasil tersebut didapatkan bahwa semakin besar konsentrasi, maka semakin besar pula zona hambat yang terbentuk.

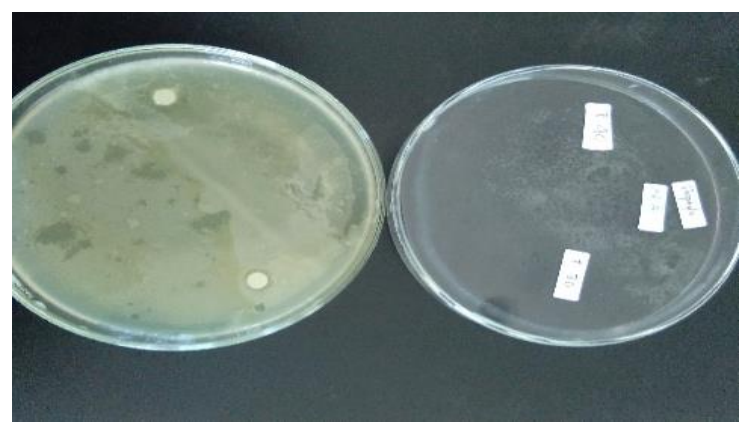

Gambar 1 Hasil Pengukuran pada F1 20\% dan F2 $30 \%$

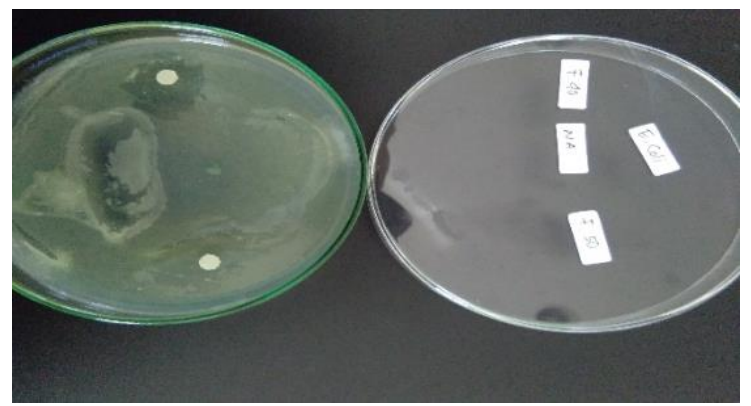

Gambar 2 Hasil Pengukuran pada F3 40\% dan F4 $50 \%$



Gambar 3 Hasil Pengukuran pada Kontrol Positif dan Kontrol Negatif

\section{Pembahasan}

Profesi keperawatan dan kebidanan

sangat memerlukan cairan antiseptic untuk menjaga diri dari terpaparnya mikroorganisme baik virus, bakteri ataupun jamur. Pemakaian antiseptic untuk keperawatan dan kebidanan pada beberapa tindakan mencuci tangan, membersihkan ruang operasi sebelum dan sesudah tindakan , membersihkan kulit bagian luka tubuh yang akan dilakukan pembedahan, membersihkan bagian yang disiapkan untuk disuntik sebelum dan sesudah ditusuk jarum dan membersihkan kulit secara keseluruhan (Gotter, 2018).

Kekayaan lokal berupa tumbuhan diketahui memiliki banyak manfaat salah satunya untuk mempertahankan kesehatan masyarakat (Noval \& Raihana, 2019). Analisis kandungan kimia ekstrak daun sirih hijau yang dilakukan menemukan 31 senyawa yang terkandung dalam ekstrak daun sirih, mayoritas senyawa aktif dari ekstrak daun sirih hijau adalah golongan fenolik yang mempunyai aktivitas antibakteri (Ni Putu 
Dinamika Kesehatan Jurnal Kebidanan dan Keperawatan Vol 11 No. 1 Juli 2020 ( ISSN: 2086-3454 EISSN: 2549-4058)

url: http://ojs.dinamikakesehatan.unism.ac.id DOI : https://doi.org/10.33859/dksm.v11i1

Potensi Antiseptik Poliherbal Daun Sirih (Piper Betle), Kulit Jeruk Nipis (Citrus Aurantifolia) Dan Tanaman Bundung (Actinuscirpus Grossus) Pada Tindakan Keperawatan Dan Kebidanan

Rahayu Kusuma Pratiwi, 2016).

Fenol yang memiliki target pada polipeptida dinding sel akan mengakibatkan kerusakan pada dinding sel. Fenol bekerja merusak membran sel dengan cara ion $\mathrm{H}^{+}$memutus gugus fosfat sehingga molekul fosfolipid terurai menjadi gliserol, asam karboksilat dan asam fosfat. Aktivitas fenol sebagai antibakteri dengan kemampuannya dalam menginaktivasi adhesi sel mikroba (molekul yang menempel pada sel inang) yang terdapat pada permukaan sel yang akan menyebabkan kerusakan pada dinding sel, sehingga membran akan bocor (mengganggu permeabilitas) dan bakteri akan mengalami penghambatan pertumbuhan bahkan dapat mengalami kematian. Flavonoid bekerja dengan cara merusak membran sitoplasma sehingga sel bakteri akan rusak dan mati. Sedangkan senyawa flavonoid berperan aktif sebagai anti inflamasi dan fenolik menunjukkan aktivitas antibakterial khususnya pada Staphylococcus aureus
Gram (+) (Kadam et al., 2012).

Analisis fitokimia ekstrak kulit jeruk nipis menunjukkan potensi antioksidan radikal bebas yang baik melalui kandungan flavonoid seperti quersetin, hesperidin dan naringerin. Naringin menunjukkan aktivitas proteksi yang baik terhadap ginjal. Naringin diketahui memiliki sifat anti karsinogenesis dan anti tumorigenesis (Kurniadari et al., 2015).

Antioksidan kandungan flavonoid direncanakan untuk dilakukan penelitian lanjutan dari penelitian ini, untuk memberikan efektivitas pendukung bahwa formulasi infusa daun sirih, ekstrak kulit jeruk nipis dan ekstrak bundung juga memiliki aktivitas antioksidan sebagai efektivitas antibakteri/ antiseptik juga bisa membersihkan adanya radikal bebas di dalam tubuh manusia.

Hasil uji fitokimia menunjukkan ekstrak etanol tanaman bundung mengandung golongan senyawa 
Dinamika Kesehatan Jurnal Kebidanan dan Keperawatan Vol 11 No. 1 Juli 2020 ( ISSN: 2086-3454 EISSN: 2549-4058)

url: http://ojs.dinamikakesehatan.unism.ac.id DOI : https://doi.org/10.33859/dksm.v11il

Potensi Antiseptik Poliherbal Daun Sirih (Piper Betle), Kulit Jeruk Nipis (Citrus Aurantifolia) Dan Tanaman Bundung (Actinuscirpus Grossus) Pada Tindakan Keperawatan Dan Kebidanan

metabolit sekunder yaitu flavonoid, tannin, saponin, fenolik, steroid dan terpenoid. Metode yang digunakan untuk uji aktivitas antimikroba terhadap bakteri Staphylococcus aureus dan Eschericia coli adalah metode dilusi cair dengan variasi konsentrasi ekstrak $0,5 \%, 1 \%, 2 \%$, $4 \%$ dan $8 \%$ dengan melihat tingkat kejernihan dari tiap sampel. Hasil uji aktivitas antimikroba dilusi cair terhadap bakteri memiliki daya hambat pada semua konsentrasi dan daya hambat terbesar ditunjukkan pada konsentrasi $8 \%$ dengan tingkatan yang paling jernih dan nilai KHM dari pengujian terdapat pada konsentrasi $1 \%$. Berdasarkan hasil tersebut, dapat disimpulkan bahwa ekstrak etanol tanaman bundung memiliki potensi aktivitas antimikroba khususnya dari senyawa metabolit sekunder flavonoid (Noval et al., 2020; Noval et al., 2019).

Pada formulasi penelitian ini menggunakan konsentrasi ekstrak bundung terkecil yang sudah memiliki aktivitas antibakteri terhadap Staphylococcus aureus yaitu konsentrasi 1\%. Dan terbukti bahwa ekstrak tanaman bundung murni yang mempunyai aktivitas antibakteri melalui kandungan senyawa flavonoid, pada formulasi infusa daun sirih (Piper betle), ekstrak kulit jeruk nipis (Citrus aurantifolia) dan ekstrak bundung (Actinosciprus Grossus) juga mempunyai aktivitas antibakteri/ antiseptik meskipun yang digunakan baru pada konsentrasi terkecil, sehingga perlu ada perancangan formulasi baru dengan meningkatkan konsentrasi ekstrak bundung yang mempunyai aktivitas antibakteri ini, karena tanaman bundung masih tersedia banyak di Kalimantan Selatan.

\section{Simpulan}

Antiseptik sangat diperlukan pada tindakan keperawatan dan kebidanan. Kombinasi daun Sirih, kulit Jeruk Nipis dan tanaman Bundung dengan konsentrasi $40 \%$ mempunyai efektivitas antiseptic yang sama dari antiseptic dengan bahan zat kimia 
Dinamika Kesehatan Jurnal Kebidanan dan Keperawatan Vol 11 No. 1 Juli 2020 ( ISSN: 2086-3454 EISSN: 2549-4058) url: http://ojs.dinamikakesehatan.unism.ac.id DOI : https://doi.org/10.33859/dksm.v11i1

Potensi Antiseptik Poliherbal Daun Sirih (Piper Betle), Kulit Jeruk Nipis (Citrus Aurantifolia) Dan Tanaman Bundung (Actinuscirpus Grossus) Pada Tindakan Keperawatan Dan Kebidanan

sintetik. Kelangkaan antiseptic dengan

bahan sintetik bisa memanfaatkan antiseptic dari bahan alam ini.

\section{Ucapan Terima kasih}

Trimakasih yang sebesar-besarnya saya ucapkan kepada Rektorat Universitas Sari Mulia beserta jajarannya yang telah mendanai dan memberikan arahan terkait penelitian ini. Serta ucapan terimakasih kepada LPPM Universitas Sari Mulia yang banyak membantu dalam proses perizinan dan penelitian

\section{Daftar Pustaka}

Aiello, \& Susan, E. (2012). The Merck Etinary manual USA. USA: Merck Shar D \& Dohme Corp.

Block, S. S. (2001). Disinfection, Steriization, and Preservation (5th ed.). Philadelphia: Lippincott Williams \& Wilkins.

Franklin, T. J., \& Snow, G. A. (2005). Biochemistry and Molecular Biology of Antimicrobial Drug Action (6th ed.). New York: Springer.

Fuadi, S. (2014). Efektivitas Ekstrak Daun Sirih Hijau ( Piper Betle L .) Terhadap Pertumbuhan Bakteri Streptococcus Pyogenes In Vitro.

Gotter, A. H. (2018). Aguide to Antiseptics.
Health, K. S. B. of. (2008). Annual Report of the State Board of Health of the state of Kansas USA:BiecioBazaar LLC. Kansas USA: BiblioBazaar LLC.

Jain, M. (2004). Competition Science Vision. India: Pratiyogita Darpan.

Kadam, P. V., Deoda, R., Shivatare, R., Yadav, K., \& Patil, M. J. (2012). Pharmacognostic, phytochemical and physiochemical studies of Mimusops Elengi Linn stem bark ( Sapotaceae ) Pharmacognostic, phytochemical and physiochemical studies of Mimusops Elengi Linn stem bark ( Sapotaceae ). Scholars Research Library, 4(January 2015), 607-613. Retrieved from www.scholarsresearchlibrary.com Scholars

Kurniadari, N., Susantiningsih, T., \& Berawi, K. N. (2015). Efek Ekstrak Etanol Kulit Jeruk Nipis ( Citrus aurantifolia ) sebagai Senyawa Nefroprotektor terhadap Gambaran Histopatologis Ginjal yang Diinduksi Cisplatin The Effect of Lime Peel Extract ( Citrus aurantifolia ) as Nephroprotector to Histopathological K. Majority, 4(9), 140-143. Retrieved fromhttps://juke.kedokteran.unila.ac.id /index.php/majority/article/view/1425

Lauma, S. W., Pangemanan, D. H. C., \& Hutagalung, B. S. P. (2015). Uji Efektifitas Perasan Air Jeruk Nipis ( Citrus Aurantifolia S ) Terhadap Pertumbuhan Bakteri Staphylococcus Aureus Secara In Vitro. Jurnal Ilmiah Farmasi, 4(4), 9-15.

Levinson, W. E. (2008). Review of Medical Mycrobyology dan Imunology (Ten). New York: The Mc GrawHillComponies,Inc.

Madigan, M. T., Martinko, J. M., \& Brock, T. D. (2006). Brock Biology of Microorganisms (11th ed.). New 
Jersey: Pearson Prentice Hall.

Ni Putu Rahayu Kusuma Pratiwi. (2016). Analisis Kandungan Kimia ekstrak daun sirih hijau. Universitas Ganesha Singaraja.

Noval, Hakim, A. R., \& Irawan, A. (2017). Advances in Health Science Research, volume 6. 2nd Sari Mulia International Conference on Health and Sciences (SMICHS 2017) Antipyretic, 6(Smichs), 359-368. Retrieved from http://creativecommons.org/licenses/b y-nc/4.0/

Noval, Melviani, Novia, \& Syahrina, D. (2020). Formulasi Dan Evaluasi Sediaan Obat Kumur (Mouthwash) Dari Ekstrak Etanol Tanaman Bundung (Actinoscirpus grossus) Sebagai Antiseptik Mulut. Jurnal Surya Medika, 6(1), 112-120. https://doi.org/https://doi.org/10.33084 /jsm.vxix.xxx.

Noval, \& Raihana. (2019). Efek Ekstrak Etanol Akar Pasak Bumi ( Eurycoma Longifolia , Jack ) Terhadap Ekspresi HRAS Pada Organ Hati Tikus Galur Sparague Dawley Pada Pemberian Doxorubicin. Jurnal Surya Medika, 5(1), 114-130.

Noval, Rosyifa, \& Annisa. (2020). Effect of HPMC Concentration Variation as Gelling Agent on Physical Stability of Formulation Gel Ethanol Extract Bundung Plants ( Actinuscirpus Grossus https://doi.org/10.4108/eai.23-112019.2298326

Noval, Yuwindry, I., \& Syahrina, D. (2019). Artikel Penelitian Phytochemical Screening And Antimicrobial Activity Of Bundung Plants Extract By Dilution Method. Jurnal Surya Medika, 5(1), 143-154.
Putri, Z. F. (2010). Uji Aktivitas Antibakteri Ekstrak Etanol Daun Sirih (Piper betle L.) Terhadap Propionibacterium acne dan Staphylococcus aureus Multiresisten. Retrieved from http://eprints.ums.ac.id/id/eprint/10092

Stoppler, \& Net, M. M. (2019). Staphylococcus Infection (Staphylococcus aureus). 